July - 2005

\title{
An Assessment of the Academic Achievement of Students in Two Modes of Part-time Programme in Nigeria
}

\author{
Kola Adeyemi and Austin Osunde \\ University of Benin \\ Nigeria
}

\begin{abstract}
This study analyses the academic achievement of students enrolled in part-times studies at oncampus and outreach centres at three dual-mode Nigerian universities, during the 1996/97 to 1998/ 99 academic years. Research subjects in this study were examination and record officers employed by on-campus and outreach institutions. A checklist was prepared to collect students' grades; these checklists were then transcribed into grade points (GPAs) for data collection purposes. Simple percentage mean $(x)$ and $t$-test statistic were used for data analysis. Interviews were also conducted with key stakeholders to add qualitative context to the quantitative data collected. This study shows that there was significant difference in the academic performance of students enrolled in the on-campus versus outreach-based, part-time programmes in selected disciplines. Also the average mean $(x)$ performance of students enrolled in the on-campus programme was higher than those students enrolled in the outreach centres. Based on the findings of this study, it is recommended that the government provide adequate funding to increase access individuals seeking higher education in Nigeria. The establishment of functional Open University system is also recommended to provide students with distant learning opportunities and likewise increase access. Several quality improvements are likewise recommended: the use of modern information technology for instructional delivery, recruitment of skilled teachers, improved teaching/ learning facilities, and strict adherence to standardized student admission requirements as specified by the National Universities Commission (NUC). We wrap up with practical suggestions, such as providing orientation sessions for outreach students to learn practical skills such as how to access library materials.
\end{abstract}

Keywords: academic achievement; part-time programmes; on-campus; outreach; distance education; quality assurance; Nigerian universities; students

\section{Introduction}

Two types of part-time degree programmes are offered by Nigerian universities: on-campus and those offered via outreach programmes. The on-campus, part-time programmes are offered at main campuses; outreach programmes are offered at satellite outreach centres, often located many kilometres from the parent campus, typically in large commercial urban centres. To gain entry into part-time programmes of study, in theory part-time students must meet the same admissions requirements as their full-time student counterparts. On-campus students studying part-time are 
taught by regular faculty, use the same facilities, and attend lectures during the evenings, weekends or vacations, as fulltime students studying on-campus. Outreach or satellite programmes, on the other hand, offer part-time programmes that are administered and delivered at designated 'outreach' centres that are physically located off-campus, outside confines of the parent institution. Outreach centres are typically located in large urban and commercial centres, so as to attract students who could afford to pay for their academic upgrading and education. These outreach centres, however, tend not to be as well equipped compared to their parent universities. Moreover, those hired to teach outreach programmes are typically recruited from outside the parent university's faculty.

The National Universities Commission (NUC) admission requirements are the exact same for both the on-campus and outreach programmes. Both programmes are to teach the same curriculum, use the same course syllabi and course contents, and administer the same examinations as used in 'mirror' programmes offered in the regular university system. All programmes of study are moderated, controlled, and approved by the senates of their respective operating universities. It is safe to assume, therefore, that there are standardized quality control measures in place that warrant the award of the same degrees and certificates to successful graduates of these programmes.

In reality, however, this is not the case. Indeed, there are currently many contentious disagreements among academics, experts, and critics as to the modus operandi and quality of education of part-time programmes offered through Nigeria's higher education system. Madunabum (1997), for example, opines that part-time - and especially out-reach programmes are inferiors due to their mode of operation and commercial aspects. Such criticisms of Nigeria's outreach programmes range from awkward lecture times, large number of students, and lack of qualified academics/ lecturers needed to teach outreach courses. Such 'substandard conditions' are typically tolerated by the public, however, primarily because outreach centres are operated under the umbrella of the parent university, and hence tend to have an aura of legitimacy about them. The fact still remains, however, that outreach centres are typically looked upon as inferior to 'real university programmes' by the general public. They believe that the quality of lecturers recruited to teach in these centres to be 'questionable,' along with the quality of instruction and course dissemination - observations that echo findings from this research study. It was found that Nigeria's outreach facilities are substandard and that the parent universities often do not exercise direct day-to-day supervision of their centres. They are extremely commercial, and many critics argue that they may trade-off academic excellence expected of normal university degree programmes in order to get paying students through the door. Obemeata (1999) for example, notes that admission requirements approved by the appropriate authorities have been unilaterally relaxed so they can enrol more and more students. In addition, Falua (1989) found that across Nigeria, outreach classes were overcrowded and that little tangible consideration was paid to lowering the lecturer-to-student ratio - conditions which he says could negatively impact truly effective teaching and learning.

These criticisms - especially those made against out-reach programmes in recent years - have resulted in government's 2001 directives to the National University commission (NUC) through the Federal Ministry of Education, which reported: “. . . the Federal Executive Council at its sitting ... considered the report on the verification visits to satellite campus and out-reach centres of existing universities ... and concluded that all campuses and study centres be closed" (Federal Ministry of Education, 2001). Operators of the outreach centres, however, refute these criticisms with the claim that the quality of programming offered to outreach students is not substandard vis-à-vis on-campus students enrolled in traditional part-time programmes. To support their claims, outreach administrators point to the 'superiority' of the facilities used to support course delivery - especially the instructional aids used. They also claim that they use the same course 
syllabi, use the standardized courses, and administer the same course examinations as their parent universities. They also cite the 'fact' that they are moderated and approved by their parent university's senate. But is this actually the case?

In the mid 1990s, a similar debate surfaced in Europe, which focused on quality and standards. This debate compelled the Socrates Programme of the European Commission to fund a year-long research study in 1997 entitled: "Making it work: European Universities and Lifelong Learning" (Taylor, 2001). The European study analysed the extent to which lifelong learning and practices were, in fact, were being practised in universities in four European countries: the Netherlands, Germany, Finland, and the UK.

Guided by the premise that technologically-driven change will result in the development of a "knowledge-based society," this study found that focus on continuous learning and retraining for all Europeans must be a top priority to ensure Europe's economic competitiveness and prosperity in the global economy (Taylor, 2001). Moreover, Europe's educational system must not only be perceived as open and flexible - it must in actual practice be open and flexible. As a result of this study, countries across the European Economic Union - and particularly those countries in this study - have proactively increased student access to open and distance education, primarily through the use of new educational technologies.

The European study also reported that emphasis on quality and quality control across the economy has been pervasive - some would say obsessive - in the 1980s and 1990s. The fact remains, however, that monitoring of 'quality' in higher education is notoriously difficult, if only because of various quality approaches to higher education. In a country like the UK, however, its educational system has evolved a complex quality assurance bodies, all of which are quasiautonomous organisations established from within the higher education system itself. According to Taylor, as competition increases between higher education institutions for external 'customers,' quality assurance issues are likely to assume even greater, more central importance.

While investigations into student performance in educational institutions may not be new or novel, the authors of this particular study argue that it is unique and important because it critically examines part-time programmes operated on-campus and in outreach centres operating in Nigeria. The finding from this research study, therefore, offer educational researchers concrete data upon which to compare and contrast on-campus and outreach part-time degree programmes in terms of their societal relevance in developing countries, as based on students' actual academic achievement. To determine if (and what) differences exist between these two programs, questions must be asked regarding the ongoing desirability of part-time and outreach programmes, and the actual quality of instruction vis-à-vis students academic achievement. These questions are:

1. What is the desirability of the two programmes?

2. What is the academic achievement of students in these programmes?

3. Is there difference between the academic performances of the students in the two programmes?

To find answers, the following research question was answered and a hypothesis tested: What is the level of compliance to the NUC minimum standard by the on-campus and outreach organised part-time programmes?

Ho1: There is no significant difference in the academic achievement of students enrolled in the on-campus and outreach part-time degree programmes. 


\section{Rationale for Part-Time Education in Nigeria}

To satisfy individuals’ quest for knowledge, and cope with growing societal-demands by school leavers and adult workers seeking more opportunity to actively participate in Nigeria's future, there has been a surge in demand for university-level education in recent years (Adeyemi, 2001; Nwadiani, 1993). In response, there has been significant expansion of Nigeria's university system, as witnessed by the establishment of 36 publicly-funded universities, and three privately owned universities (National Population Commission, 2000). Such development can be seen as phenomenal in the sense that Nigeria's university system has grown from only one university in 1960, to six in 1970, to 13 in 1980 (National Universities Commission, 1981), to 36 new universities by 2000. Student enrolment has also increased dramatically. For instance, enrolment was 77,791 in 1980; 172,463 in 1990; and 253,121 in 1996 (NUC, 1989; 1990; 1997).

The above figures, however, constitute only a small fraction those individuals actually seeking higher education; the fact remains that for all those who have applied and passed the university entry matriculation exams, space remains limited and only a lucky few can be enrolled in university-level studies (Obemeata, 1999; Omoregie, 1999). According to Nwadiani (1993), between 1980 and 1990, 1,887,576 Nigerian citizens applied for entrance into university, while only 316,528 (16.8\%) were admitted, thereby leaving the remaining individuals (82.2\%) stranded, without access. This arguably dismal statistic can be compared to UNESCO's findings, which showed a huge increase in university-level student enrolment in developed countries in the 18-23 age group - which jumped from 15.1 percent in 1969; to 21.7 percent in 1979; to 30.7 percent in 1980; to 40.2 percent in 1991. UNESCO predicts a sizable increase in student numbers enrolled in higher education worldwide - from 65 million in 1991; to 79 million in 2000; to 97 million in 2015; and 1000 million by 2025 (Taylor, 2001).

Increasing demand and the recent and unprecedented expansion of its higher education system has placed tremendous pressure has been placed on the government's shoulders to fund all levels of higher education in Nigeria (Adeyemi, 1995; Ejiogu, 1997). Unfortunately, due to an economic recession that is currently crippling the country's economy, government funding for Nigeria's universities has dwindled dramatically. Current economic conditions have forced the government to issue directives their universities, asking them to generate additional funds internally (i.e., forprofit courses) to help finance basic university programmes.

Thus, the double-edged need to increase access to higher education AND generate much needed revenue has informed the intent, development, and ultimately the introduction of current part-time programmes of study offered by Nigeria's university system. According to Obemeata (1999) and Afe (1999) the expansion of part-time programmes must aim to accommodate both students seeking a university degree, as well as provide on-the-job training opportunities for those individuals who require new skills and/ or academic upgrading. In chronicling the relevance of outreach part-time programmes, Akintayo (1990) concluded that due to under-utilization of resources (i.e., physical capacity), coupled with increasing student demand for access to higher education opportunities, university's must implement outreach programmes to address growing demand. Similarly, Rumble and Harry (1982), Jianshu (1988), McIsaac, Murphy, and Demiray (1988), Bernard and Amundsen (1989), all agreed that open access to distance learning programmes will improve student access to higher education.

The need to accommodate thousands of Nigerians yearning for a university education formed the crux of discussions between the Joint Admission and Matriculation Board (JAMB) and the Commonwealth of Learning (COL) during the World Education Market in Vancouver, Canada (The Guardian, 2001). Faced with ever increasing demand for higher education across Nigeria, 
(e.g., over 700,000 Nigerians applied to attend university during the last university matriculation examination), JAMB's registrar, Prof. Bello Salim voiced his concerns to COL's president, Gajaraj Dhanarajan, that increased access to distance learning education opportunities was essential to Nigeria's future welfare (The Guardian, 2001). Prof. Bello Salims' concerns are reflected in hard numbers. In 1999/ 2000 approximately 460,000 Nigerians wrote the UME; and in 2000/ 2001 over 700,000 in 2000/2001 wrote the UME - of which only about 10 percent of will eventually get placed. Prof. Bello Salim: "I am deeply worried about those young boys and girls who desire to study in our universities will, unfortunately, have access to limited spaces" (The Guardian, 2000, June 28, p.42).

In 1984, an attempt was made to address problems of access when an Open University was established to offer distance and part-time degree programmes. These programmes, however, were discontinued in 1985 due to unstable political considerations. The present government, however, is resurrecting Nigeria's distance and part-time educational system, as witnessed by the dramatic expansion of access to university education in recent years.

The need of raising alternative sources of revenue (to supplement government funding) has resulted in a dramatic increase in part-time programmes offered by many universities (Obemeata, 1999). These part-time programmes are offered on a 'for-profit' basis, which in turn financially subsidize regular students enrolled in Nigeria's federal universities, who are required to pay tuition fees. Nonetheless, Briner and Pauli (1971) as cited in Omoregie (1999) saw the implementation of part-time programming as a viable strategy to increase access to those desirous of higher education. In sum, according to these academics, if a society or a political system fails to offer its people access to basic and higher education, the whole population suffers.

\section{Method of Study}

This descriptive study used an ex post facto design. At the time of this study, there were 36 state and federal government owned universities in Nigeria. All 36 universities operated one form of part-time degree programme, either university-based (on-campus) or satellite-based (outreach). Only 12 universities, however, operate both on-campus and outreach programmes. It is these 12 dual-mode universities that formed the population of our study. These 12 dual-mode universities were then further divided into three sub-groups: (1) first generation universities (established before 1970); second-generation universities (established between 1971 and 1983); and new generation universities (established from 1985 onward) as classified by the National Universities Commission (NUC). From each generation, one university was randomly selected. In total, three universities were randomly selected for our study (25 percent of Nigeria's dual mode universities).

One thousand students were then selected from each of the programmes (on-campus and outreach), translating to 200 students per discipline studied (five disciplines in total). The five disciplines selected for the study - Public Administration, Accounting, Computer Science, Business Administration, and Technical Education - were chosen because they are the most sought after disciplines and most universities offer these programmes in both on-campus and outreach modes. It should also be noted here, however, that most part-time programmes are geared towards the delivery of management-type courses, because such courses are less costintensive to design and deliver compared to science courses, which are obviously more expensive (i.e., no need for laboratories and workshops). In addition, management courses are relatively easy to administer and teach both on-campus and at the outreach centres. Finally, current market conditions are such that many Nigerians are actively seeking out managerial courses, so they can work in big multinational companies and make big and quick money. Hence, at present there is a 
huge demand for these types of courses. Additionally, based on pure pragmatics, because parttime programmes generate much needed revenue, universities are very keen in increasing access to areas of education that can attract more students and hence more money to underwrite their overall activities.

Finally, it is important to note that this study covered the 1996/97 to 1998/99 academic years. An ex post facto design was used because growing labour unrest throughout Nigeria's university system has resulted in interrupted academic years. As such, these particular years were analysed because they were complete and thus yielded more reliable data.

We prepared a standardized checklist to collect student score data. We then asked the examination and records officers employed by the three universities and outreach centres in our study, to populate these checklists with student scores. Data from the checklists (students' scores) were then translated into grade point averages (GPAs), as based on criteria established by the National Universities Commission's (NUC) guidelines (see Figure 1). To flesh out our quantitative data with qualitative data, staff and participants in the programmes were interviewed on the relevance, desirability, and sustainability of their respective on-campus or outreach programmes, using semi-structured interviews. The interviews were used to provide qualitative context to the quantitative data collected. The GPAs of students enrolled in the various programmes were compared to determine whether statistically significance differences existed between them. In other words, the academic performance of the randomly sampled students enrolled the five selected disciplines in both on-campus and outreach programmes of study were statistically compared.

Table 1. GPAs as based on criteria established by the National Universities Commission's (NUC) guidelines.

$$
\begin{aligned}
& \mathrm{A}=70 \% \text { and above }=5 \text { points } \\
& \mathrm{B}=60-69 \%=4 \text { points } \\
& \mathrm{C}=50-59 \%=3 \text { points } \\
& \mathrm{D}=45-49 \%=2 \text { points } \\
& \mathrm{E}=40-44 \%=1 \text { points } \\
& \mathrm{F}=0-39 \% \quad=\quad 0 \text { points } \\
& \text { Soure: MUC Aproved Soning and Grading Spstem Universty of Benin } \\
& \text { (ntemal Memorondm July 22. 109) }
\end{aligned}
$$

The NUC has determined that the following factors can impact on student academic achievement. These factors are: teaching manpower; quality of instructional delivery; entry requirements; facilities/ equipment; course contents and mode of assessment. From these factors, the NUC developed 'minimum operational standards' that must be met in delivering degree programmes and in awarding degrees. The NUC parameters for minimum standards in Nigerian Universities are as follows: 
1.(a) Teaching manpower: professorial (20\%); Senior Lecturer (35\%); other (45\%)

(b) Teacher/ Student ratio: ranged between 1:24 for Education courses to 1:10 for Medical Sciences, Sciences, Engineering, Pharmacy, and Agriculture.

(a) Academic staff/ Academic support staff ratio:

- One senior administrative staff to 12 academic staff

- One senior technical staff to 20 academic staff

- Two junior non-technical staff to three academic staff (for all academic departments and units).

Based on this NUC's minimum standards cited in Table 1, this study assumes that quality of instructional/ educational delivery of will be determined by the prescribed NUC's minimum standard ratios above.

2. Library Facilities: The NUC prescribes a minimum standard for library services, with adequate number of books and journals for university departments and faculties.

3. Entry Requirements: The NUC recommends five credit pass (including English and Mathematics) at Ordinary Level, and at least a one credit pass at Advanced level or other related certificate for direct admission to any 5-year or 4-year degree programme respectively. Admission requirements for the part-time programmes (on-campus and outreach) are flexible for mature candidates over age, which is 35 years and above.

4. Instructional Facilities/Equipment: The NUC prescribes a minimum standard for laboratory, workshop, accommodation, recreation, lecture room/halls, etc.

5. Course Contents: Curricula appropriate to class/ level are determined by the senate of the various universities.

6. Mode of Assessment: NUC prescribes ac course of continuous assessments, tests, and examinations of the modes of student assessments.

Based on these minimum standards, the following values were used to rate the compliance level of the outreach centres and the on-campus programmes.

\footnotetext{
* Very good - 5 points

* Good - 4 points

* Fair - 3 points

* Poor - 2 points

* Very poor - 1 point
}

A questionnaire that focussed on the NUC parameters was developed and administered by the researchers through personal visits to the institutions. Data and information obtained were analysed by using simple mean, percentage and $t$-test statistics.

\section{Testing Institutional Input Factors and Students Academic Achievement}

Research Question: What is the level of compliance to the NUC minimum standard by the oncampus and outreach organised part-time programmes? 
Answers to this question are in Table 2.

Table 2. Rating of Academic Performance induced Factors Based on NUC Minimum Standards (Level of Compliance)

\begin{tabular}{|l|l|c|c|c|c|c|c|}
\hline & Factors & \multicolumn{2}{|c|}{ Univ. 1 } & \multicolumn{2}{|c|}{ Univ. 2 } & \multicolumn{2}{|c|}{ Univ. 3 } \\
\hline 1 & Teaching manpower & 4 & 2 & 3 & 2 & 3 & 1 \\
\cline { 2 - 8 } 2. & $\begin{array}{l}\text { Quality of institutional } \\
\text { delivery }\end{array}$ & 3 & 1 & 4 & 2 & 2 & 1 \\
3. & Entry requirements & 4 & 2 & 4 & 2 & 3 & 2 \\
4. & $\begin{array}{l}\text { Instructional facilities/ } \\
\text { equipment }\end{array}$ & 4 & 1 & 3 & 1 & 3 & 1 \\
5. & Quality of coursecontents & 4 & 3 & 4 & 2 & 4 & 3 \\
6. & Mode of assessment & 4 & 2 & 3 & 3 & 4 & 2 \\
\hline
\end{tabular}

$\begin{array}{lll}\text { Note: } & \text { Figures in parenthesis represent percertage response rating } \\ \text { Ocp } & = & \text { On-campus programme } \\ \text { Op } & = & \text { Outreach programme }\end{array}$

As based on the NUC's minimum standards for academic performance factors, the data presented in Table 2 shows that neither the on-campus or outreach programmes met the NUC's minimum standards. Moreover, a consistent rating pattern between on-campus and outreach programmes can be noted - with the on-campus programmes showing more favourable results than 'same/ similar' programmes offered by the outreach centres.

These findings indicate that the teaching/ learning processes use in these programmes do not meet the minimum standards as set by the NUC, which in turn, may negatively impact student achievement. These findings also show that on-campus students tend to learn more and perform better academically than their student counterparts enrolled in the outreach centres. To address this position the following hypothesis was tested.

Hypothesis: There is no significant difference in the academic achievement between students in the on-campus and outreach part-time programme. 
Table 3. Summary of $t$-Test Analysis of the Students Academic Achievement between Oncampus and Outreach Part-time Degree Programmes

\begin{tabular}{|l|l|c|c|c|c|c|c|c|}
\hline SNN & \multicolumn{1}{|c|}{ Degree Courses } & \multicolumn{3}{c|}{ On-Campus } & \multicolumn{3}{c|}{ Out-Reach } & Calculated \\
\hline & & N & SD & X & N & SD & X & t-Value \\
\hline 1. & Public A dministration & 200 & 14.61 & 42.10 & 200 & 11.76 & 36.84 & 14.61 \\
2. & Accounting & 200 & 16.48 & 62.42 & 200 & 21.98 & 64.36 & -18.86 \\
3. & Computer Science & 200 & 10.53 & 48.52 & 200 & 12.90 & 40.12 & 24.71 \\
4. & Business A dministration & 200 & 10.50 & 44.12 & 200 & 8.75 & 35.72 & 27.10 \\
5. & Techuical Education & 200 & 9.34 & 43.96 & 200 & 7.66 & 32.81 & 38.45 \\
\hline
\end{tabular}

Table 3 above shows the calculated $t$-values for the degree courses (Public Administration at 14.61; Accounting at -18.86; Computer Science at 24.71; Business Administration: 38.45) are greater than the table/ critical value of 1.96 at alpha level of .05. Therefore the hypothesis, There is no significant difference in the academic achievement between students in the on-campus and outreach part-time programme, is rejected. From this finding, it can be logically concluded that there is a significant (negative) difference between in the academic achievement of students enrolled in the on-campus and outreach centre-based part-time programmes in the disciplines selected for this study.

\section{Discussion}

This study shows that there is a significant gap between supply and demand for higher education throughout Nigeria. It also shows that there is logical justification for expansion of Nigeria's higher education system and that the part-time, degree granting programmes do play a significant role in addressing societal demand for access to higher education. This finding echoes similar developments found across the globe (Asmal, 2000; Taylor, 2001).

Our study has revealed, however, that the standard or quality of learning, as currently on offer in the both part-time on-campus and outreach centres could hamper effective teaching/ learning. Moreover, the part-time programmes offered through the outreach centres were found to be inferior to similar/ same part-time programmes of study offered on-campus, with the exception of Accounting. In sum, the level of compliance to the minimum standard set by Nigeria's quality control agency for the university education (NUC) was found to be below average for both programmes (see Table 3). While the standards of the on-campus programmes were superior to that of the outreach centres, they too remained below national standards.

Unfortunately, the lack of a coherent and reliable information technology infrastructure does not help matters, particularly in the area of knowledge dissemination and information distribution, especially as flowing from the university campuses to their respective outreach centres. These are critical technological issues that impact seriously on student learning, and by logic, could likely translate into lower/ substandard academic performance.

Our findings also showed that students enrolled in the on-campus, part-time programme performed better than their counterparts in the outreach centres, with the exception being 
Accounting, which recorded a higher mean score in the outreach centres. This finding, however, could be explained by the fact that experienced professionals (i.e., Chartered Accountants) are typically hired to teach in the outreach centres on a part-time basis. Moreover, 'teacher retention rates' for those teaching accounting on university campuses tends to low, so less experienced professionals make up the ranks of the on-campus lecture workforce (Adeyemi, 2000). Indeed, most accountants typically opt for better-paid employment scenarios in Nigeria's banks, oil companies and other industries - and these are the skilled accounting professionals that typically teach in outreach centres. It is not surprising, therefore, to see the mean performance for Accounting courses taught in the outreach centres to surpass those of the on-campus Accounting programmes, simply because these outreach courses are taught by 'gurus' currently working in the field.

For the remaining four programmes in this study, on-campus students (as seen in the mean scores) performed better than their counterparts studying the same courses at outreach centres. This finding suggests that on-campus university environments provide more conducive teaching/ learning environments and yield (albeit still below standard) better academic performance as seen in the mean scores. Regular university faculty also teach the part-time on-campus courses. These experienced teachers and lecturers have more access to - and arguably more familiarity with - the larger array of campus-based facilities such as libraries, lecture rooms, etc. Part-time students' studying on-campus also have more informal contact with their full-time student counterparts - a process of 'academic osmosis' that enhances student learning, an observation that has been corroborated by Obemeata (1999) who noted that students typically learn better through informal discussion among themselves.

Although the entry requirements for both programmes are the exactly the same, our investigations revealed that the NUC's admission procedures at the outreach/ satellite campuses are abused. This finding may explain why government ordered the closure of outreach/ satellite programmes. In sum, differences found in student performance in the two programmes may be attributed to adulterated admission processes. The low mean performance by students enrolled in the outreach centres seem to confirm the fears raised by Madunabuan (1997) and Falua (1989), who questioned the quality of knowledge dissemination and educational facilities available in the outreach centres, which they say operate well below national standards. Clearly, this could negatively influence learning outcomes.

This study showed significant differences exist between the academic achievements of oncampus and outreach students. This finding is not surprising, however, owing to the fact that the two programmes operate in distinct, different teaching/ learning environments, many conditions of which were described in greater detail earlier. Nonetheless, students enrolled in the on-campus part-time programme were also found to be armed with better academic orientations and exposures than their outreach counterparts, a finding that suggests that base-line entry requirements are lower for outreach students.

Based on the above findings and discussion, critics who find part-time programmes lacking especially those in outreach centres - are typically met by counter-arguments of those critics who say the trade-off (lower standards) is worth turning a blind eye to NUC minimum standards. Nonetheless, the findings of this study do support the fears raised by Madunabum (1997), who asserted that quality programming is central to producing quality graduates, and that graduates tend to reflect the quality of intakes and their learning environment - and that Nigeria's part-time programmes, offered on-campus and through outreach centres, are producing inferior graduates. Our findings may also offer an explanation for the federal government recent decision to suspend operations at the outreach and satellite centres until restructuring is complete. The pressing need to dramatically increase access to higher educational opportunities, however, does seem to be 
outweigh concerns raised by critics of the outreach centres and the findings of this study - in particular, those programmes that aim to train and educate mature candidates who may not be well equipped to participate academically and may, by necessity, require more flexible, open access to upgrade education.

\section{Limitations}

While the finding of this study are persuasive, the study itself holds limitations. Several extraneous factors that could influence our finding were not within the scope of this study. Such factors include: learning environment, especially for outreach programme, facilities available, quality of staff, period of study, etc. For further research, it is suggested here that similar studies can be carried out at the polytechnics and colleges of education levels, since they also operate the on-campus and outreach programmes.

\section{Conclusion and Recommendations}

Owing to growing demand for university education, part-time programmes and other forms of distance education alternatives designed to increase student access to higher educational opportunities in Nigeria are indispensable. As this study clearly shows, however, increasing access may result in the provision of substandard facilities and less than optimal teaching situations. Clearly, failure to adhere to the basic minimum standards established by the NUC will likely produce inadequately prepared graduates - those very people who need quality skills and knowledge to guide Nigeria's future social and economic development. This study also found significant differences in academic performance of those students enrolled in the part-time oncampus and outreach programmes. This finding is explained by difference in quality of the two programmes (e.g., type of faculty and facilities used).

Findings from this study warn of serious implications for Nigeria. While it is evident that Nigeria must dramatically increase access for its growing population so they and the nation can benefit from opportunities afforded by a higher education, this takes money combined with strategic planning to make it happen. As such, the call is made here for all stakeholders - governmental, public, and private sector - to increase funding, so both meaningful and strategic expansion of existing facilities (on-campus and outreach) can be achieved to deliver the quality of instruction need to meet the NUC's basic minimum standards.

To expand access, Nigeria's governments must act quickly to establish an integrated, high-quality open university system (i.e., a system comprised of distance learning programmes, outreach programmes, and on-campus programmes of study). It is also suggested that an overarching quality control agency independent of the NUC be established to review, monitor, and guide the activities of the various part-time, distance, and outreach programs that currently operate under the purview of Nigeria's various public and private university senates. Minimum standards monitored by this proposed independent quality control agency should include: teaching/ learning facilities; admission requirements; quality of faculty/ lecturers; and student to faculty ratios.

Nigeria - like many nations across Africa and throughout the developing world - also lags behind developed nations in terms of infrastructure to support learning technologies. Nigeria's major telecommunication carrier (NITEL) is largely inefficient; continued private multinational participation in the funding and provision of information technology could therefore be of immense assistance to Nigeria's long term development. 
Students enrolled in outreach centres should be provided more access (e.g., orientation sessions) with their parent universities, which will enable them to learn how to access on-campus facilities such as libraries and workshops. If, and where possible, examinations should be conducted on the main campuses of the parent universities. In terms of admission requirements, it is suggested that the university admission criteria be rigidly applied to all potential applicants. Nonetheless, the fact remains that because many part-time programmes aim serve the educational needs of mature learners, and as such, flexibility in admission are essential so as not to impede access. Therefore, remedial learning programmes should be put in place to help mature learners obtain the basic skills and knowledge they need to become rigorous students, and true contributors to Nigeria's future.

Finally, more attention must be paid to the expansion and development of other tertiary forms of higher education (e.g., polytechnics, monotechnics, vocational institutions, and other professional colleges) in order to expand access to higher education.

These suggestions are imperative as Nigeria joins the rest of the responsible global family in increasing access to education at all levels, and to provide the qualitative manpower to cope with the over-increasing areas of human developmental endeavours.

\section{References}

Adeyemi, J. K. (1995). “An analysis of resources allocation and productivity level of Secondary education in Nigeria” Nigerian Journal of Professional Studies, 3(1), 4 - 6.

Adeyemi, J. K. (2000). “Academic manpower needs of nigerian universities” Higher Education Review, 32(2) $36-44$.

Adeyemi, J. K. (2001). "Equality of access and catchment area factor in university admissions in Nigeria” Higher Education, 42(3) 307 - 332.

Afe, J. O. (1999). "Teacher education part-time programme in Nigeria: History, rationale, problems and prospects” In Oshodin O. G., Ehiametalor, E. T., and Awanbor, D. (Eds.) Teacher Education Part-Time Programmes in Nigeria. Benin City, Nigeria: University of Benin Publishers, 7 - 12.

Akintayo, M. O. (1990). The relevance of outreach programmes to capacity under-utilization of resources in higher education in Nigeria in the '90s. The Educational Planner, 1(3/ 4), $89-103$.

Asmal, K. (2000). Characteristics of elements of a lifelong learning higher educational institution. Ministerial speech, conference on Lifelong Learning, Higher Education and Active Citizenship, Cape Town, South Africa, October 10-12. Hosted by UNESCO and Danish National University of Education.

Brimner, M. A., and Pauli, l. (1971). Wastage in Education: a world problem. Paris: UNESCO/ IIEP, 9.

Bernard, R. M., and Amundsen, C. L. (1989). Antecedents to dropout in distance education: does one model fit all? Journal of Distance Education, 1(2), 25 - 46. 
Ejiogu, A. (1997). The changing fortunes of higher education in Nigeria. In A. Ejiogu and K. Ajayi (Eds.) Emergent Issues in Education, 2. Lagos, Nigeria: University Consult.

Falua, O. (1989). Continuing education or mis-education centres: an absolution of the problem of underachievement among Nigerian students. African Journal of Educational Management, 3(1), 67 - 74.

Federal Ministry of Education (2001). Closing of outreach Centres and Universities' Satellite campuses. A Federal Government Circular to all Universities and other related institutions. Abuja: Federal Ministry of Education.

Jianshu, Z. (1988). The development of higher distance education in China. Developing Distance Education, 450 - 452.

Madunabum, M. A. (1997). In-service education a neglected dimension of the professional development of the Nigerian science teacher. West African Journal of Educational Research, 1(2), 183 - 186.

McIsaac, M. M., Murphy, K. L., and Demiray, U. (1988) Examinating distance education in Turkey. Distance Education, 9(1).

National Population Commission (2000). Annual report, Abuja, NPC.

National Universities Commission (1981). Annual report, Abuja, NUC.

National Universities Commission (1989). Annual statistical digest (1980/81 - 85/ 86). Abuja, NUC.

National Universities Commission (1990). Annual report, Abuja, NUC.

National Universities commission (1997). Statistical information on Nigerian universities. Abuja, NUC.

Nwadiani, M. (1993). Planning higher education in Nigeria in the '90s and beyond: Rationale and challenges. Journal of Higher Education 16(2), 283 - 292.

Obemeata, J. O. (1999). Part-time Programmes: Concept and development in Nigeria. In O. G. Oshodin, E. T. Ehiametalor, and D. Awanbor (Eds.) Teacher Education Programmes in Nigeria, Benin City: University of Benin Publishers, 1 - 6.

Omoregie, O. S. B. (1999). Teacher education part-time programme in Nigerian tertiary institutions as strategy for arresting wastage in education. Benin City: University of Benin Publishers.

Oshodin O. G., Ehiametalor, E. T., and Awanbor, D. (Eds.) Teacher Education Part-Time Programmes in Nigeria. Benin City, Nigeria: University of Benin Publishers.

Rumble, G., and Harry, K. (1982). The distance teaching universities. London: Groom Helm. 
Taylor, R. (2001). Lifelong Learning in Higher Education in Europe: Myth or reality? Adult Education and Development, 56, 127 - 146.

The Guardian (2001). COL discuss distance learning. June 28. Lagos, p. 42.

SOMERIGHISRESERVED

